\title{
Seasonal Variation of Functional Traits in the Fish Community in a Brackish Lagoon of the Po River Delta (Northern Italy)
}

\author{
Mattia Lanzoni, Mattias Gaglio *(D), Anna Gavioli, Elisa Anna Fano (D) and Giuseppe Castaldelli (D) \\ Department of Life Sciences and Biotechnology, University of Ferrara, Via L.Borsari 42, 44121 Ferrara, Italy; \\ mattia.lanzoni@unife.it (M.L.); anna.gavioli@unife.it (A.G.); fne@unife.it (E.A.F.); ctg@unife.it (G.C.) \\ * Correspondence: gglmts@unife.it
}

check for updates

Citation: Lanzoni, M.; Gaglio, M.; Gavioli, A.; Fano, E.A.; Castaldelli, G. Seasonal Variation of Functional Traits in the Fish Community in a Brackish Lagoon of the Po River Delta (Northern Italy). Water 2021, 13, 679. https://doi.org/10.3390/w13050679

Academic Editor: Thomas Hein

Received: 31 December 2020

Accepted: 26 February 2021

Published: 2 March 2021

Publisher's Note: MDPI stays neutral with regard to jurisdictional claims in published maps and institutional affiliations.

Copyright: (c) 2021 by the authors. Licensee MDPI, Basel, Switzerland. This article is an open access article distributed under the terms and conditions of the Creative Commons Attribution (CC BY) license (https:// creativecommons.org/licenses/by/ $4.0 /)$.

\begin{abstract}
Brackish lagoons are highly productive systems that support fishing and aquaculture activities with important revenue. At the same time, they function as fundamental habitats for the conservation of a number of species that use lagoons for reproduction and feeding. The present study aims at describing the seasonal structural and functional variations of fish communities in the Fattibello lagoon, a small but important nursery ground of the Po River delta (northern Italy), historically exploited for fishing. The fish community was sampled monthly over a six-years' period (2009-2014). The results were normalized in catch per unit of effort (CPUE) and are expressed both as individual abundances (ind/CPUE) and biomass (g/CPUE). Higher biodiversity levels were observed in autumn, when both lagoon residents and marine species coexist, and summer, for individual abundances and biomass. Biomass was a better descriptor than individual abundance of the functional use of the lagoon. In autumn, the lagoon resident species increased significantly, while marine feeding ground species decreased. Vice versa, lagoon residents decreased in winter, when the lagoon were mainly used as feeding ground by marine fishes. Marine migrating species were present throughout the whole year. Overall, the lagoon serves as (i) reproduction habitats for different species, as well as habitat for the pre-reproductive period for the European anchovy; (ii) nursery grounds for a number of commercial species; and (iii) habitats for lagoon resident species, supporting them for the whole life cycle. Overall, the results highlight the fundamental conservation role of the lagoon throughout the whole year, and that seasonal structural and functional patterns of fish communities should be carefully considered when seeking to harmonize direct uses, such as fishing and bivalve farming, as well as nature conservation.
\end{abstract}

Keywords: ecosystem function; community structure; seasonal dynamics; tidal wetlands; aquatic conservation

\section{Introduction}

Brackish lagoons are naturally stressed wetlands where interactions of marine and inland waters with terrestrial domains result in continuous changes of environmental conditions in space and time [1,2]. Temporal and spatial heterogeneity make them hot-spots for aquatic biodiversity [3,4], universally considered worthy of particular conservation efforts. With this in mind, the Ramsar Convention [5] recognized brackish lagoons as being among the fundamental habitats for aquatic biodiversity conservation, and defines them as lagoons with at least one relatively narrow connection to the sea. The Convention also encompasses the so-called "wise use" that requires the maintenance of ecological characters in the sustainable development context, further raising attention to their ecological role. Their relevance in delivering ecological functions and ecosystem services in coastal and deltaic landscapes is also well-documented in a growing body of literature [6-9].

The ecological functions fulfilled by brackish lagoons and their biotic communities are intimately interrelated [10,11] and governed by complex relationships that involve environmental changes naturally occurring in transitional ecosystems. Additionally, transitional ecosystems are site of many human activities, such as fishing, aquaculture, tourism 
and related indirect impacts (e.g., pollution and alien species introduction). All these human actions may exert stresses and alter ecological structures, which in some case are seriously threatened [12]. This framework urgently requires the understanding of how biotic communities and ecological functions interact within socio-ecological systems, as in the case of brackish lagoons in deltaic landscapes. Brackish systems support diverse biotic community structures, thanks to the co-occurrences of specialist species with restricted distributions and others taxa inhabiting lagoons for a restricted time span or for specific purposes [13]. Some species are adapted to face the stressed conditions of brackish lagoons, e.g., salinity variations, taking advantage of inherent resources and conditions and spending their whole life cycle in these habitats [14]. At the same time, brackish lagoons are also visited by freshwater and marine species whose occurrence is governed by cyclic variations of environmental conditions, thus being important elements for the functioning of marine and coastal ecosystems. Consequently, biotic assemblages can be conveniently classified according to their functional use of the lagoon. For instance, Pihl et al. [15] classified habitat use by fishes in European estuarine systems into four main groups: spawning grounds, nursery grounds, feeding grounds, and pathways in diadromous migrations.

Biotic aggregations, particularly in the case of fishes, vary throughout the year following cyclic features of local climate, weather, and other site-specific environmental conditions. Seasonal variation patterns represent the most important causes of cyclic environmental changes affecting and driving aquatic communities in time. In temperate climates, seasonal variations in temperature, solar radiation and photoperiod drive primary productivity throughout the year, thus affecting the availability of trophic resources for consumers and water chemistry [16]. Additionally, when brackish lagoons are connected to the sea, variations of seasonal tides may drive the moving of species [17] and cause sharp change of salinity levels $[18,19]$. All these effects regulate the occurrence of species and their interactions throughout the year, determining seasonal patterns of community structures and environmental functions in brackish lagoons.

Fish communities represent ideal models for describing variations of both community structure and ecosystem functioning in brackish lagoons, thanks to their high mobility. Their occurrence is a consequence of a number of environmental factors, including the connectivity degree of the lagoon with the sea and inner waters, resource availability, climate, and tidal changes $[17,20]$. Moreover, as coastal lagoons are highly productive systems, fishery is an important economic activity that requires the knowledge of natural stocks dynamics [21]. The management of fisheries has been identified as the main instrument to maintain lagoons' ecological features and prevent the degradation of their sensitive habitats, both from socioeconomic and environmental points of view [21,22]. In fact, sustainable harvest fisheries require high-functioning ecosystems, and the maintenance of ecosystem functions is fundamental to guarantee the presence of natural stocks in a long-term view.

The present study aims to describe the functional role of the Fattibello lagoon, a little brackish lagoonal ecosystem of the Po River delta (northern Italy) exposed to wide variations of environmental parameters, which determine the seasonal variations of biotic communities $[17,23]$. Although presenting a relatively small extension, this little microtidal lagoon has been extremely important since the Renaissance as nursery ground and way through for the juveniles entering the much larger (at that time, more than $400 \mathrm{~km}^{2}$ ) managed systems of the semi-closed lagoons of Comacchio (Ferrara), which are used for extensive aquaculture (for details, please see [24,25]). Presently, the Fattibello lagoon is an important site for aquaculture and traditional fisheries, but has gained a central role in biodiversity conservation, after the institution of the Po Park of the Po Delta.

The results will contribute to the understanding of the fundamental functional role of brackish lagoons in the wider perspective of ecosystem services for human well-being, as well as their relationships with biodiversity conservation. 


\section{Materials and Methods}

\subsection{Study Area}

The Fattibello lagoon is a microtidal brackish lagoon of approximately 730 ha located in the north-western part of the Adriatic Sea (Figure 1). The basin is the northernmost lagoon of the much larger lagoonal system of Comacchio, an area renowned worldwide for its long-standing tradition of extensive European eel (Anguilla anguilla L.) aquaculture. Today the whole ecosystem is protected and included in the Po River Delta Park (northern Italy). The area represents a remnant ecosystem of an ancient system of transitional wetlands that characterized the deltaic landscape of the Po river in the past [7,9]. The salinity ranges seasonally from 13 to $31 \mathrm{psu}$, according to tides, driving fluctuations in biotic communities. The average tidal event in this area has a magnitude of approximately $40 \mathrm{~cm}$ with a rather variable tidal range (5-90 cm tidal amplitude). The lagoon has an average water depth of $1 \mathrm{~m}$, varying from a minimum of a few centimeters on the shallowest sandbars to a maximum of $3 \mathrm{~m}$ in the deepest channels. The lagoon has a heterogeneous substrate, including muds and silts as well as sands and harder substrates (mussel beds, shell hash). Water currents reshape the softer sediments, sometimes creating temporally shifting patterns of sandbars. The Fattibello lagoon is connected to the sea through the Navigabile and Logonovo channels, two large waterways that nowadays are used mostly for recreational boat transit. The Navigabile channel also extends inland and, together with the Fosse Foce channel, can occasionally input freshwaters into the lagoon. Both channels are transitional yet simplified habitats, used by marine and brackish fishes to move between sea and lagoon environments, constituting the only passage between them. The Fattibello lagoon is subject to different needs and uses. Fishery is still an important local traditional and economic activity that is based on the presence of several commercial species. Little portions of the lagoon and almost the whole extension of the channels are used for Manila clam farming. The whole area is included in the Natura 2000 network, and the demand for environmental conservation requires the sustainable use of natural resources.

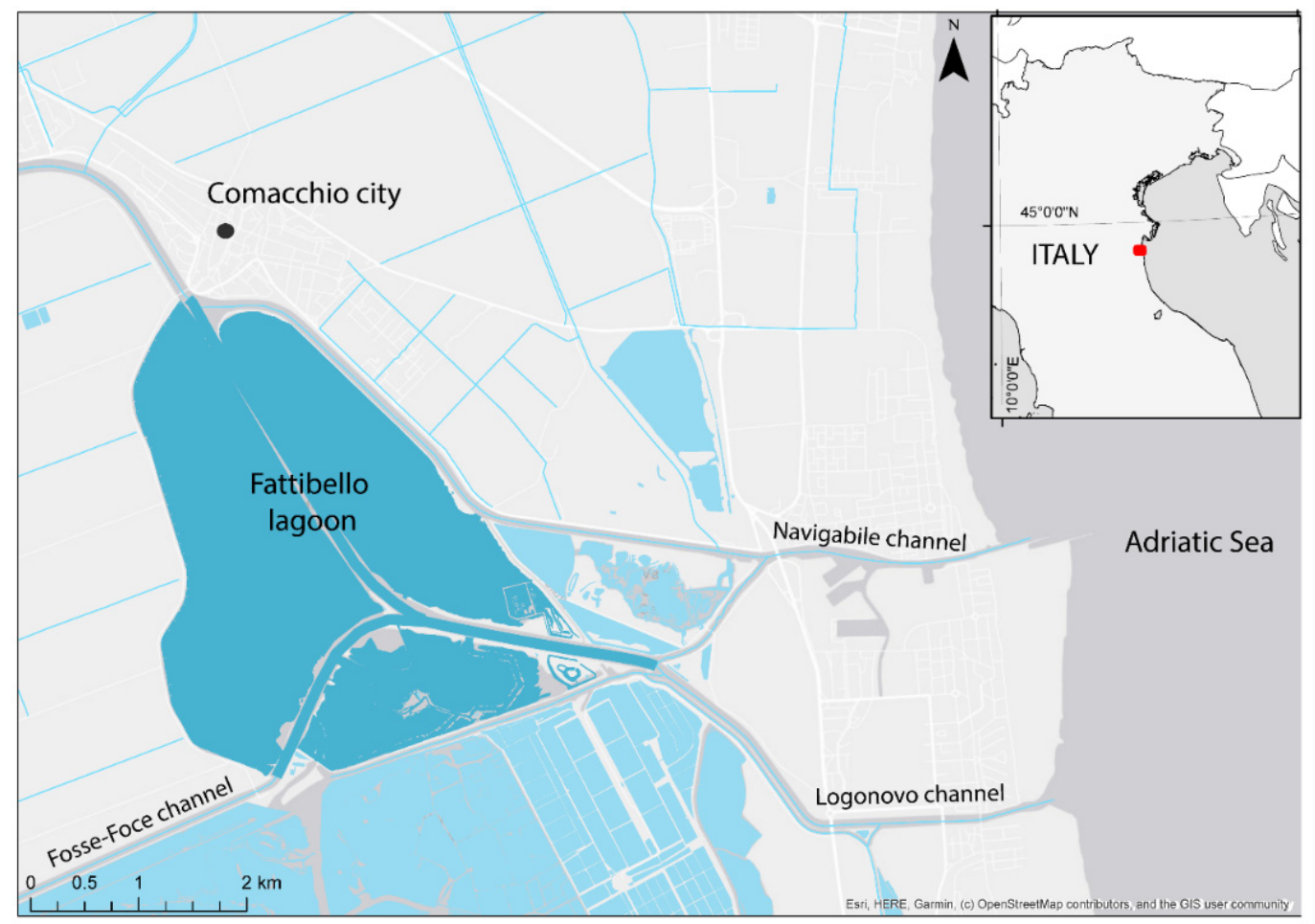

Figure 1. Map of the study area, showing the Fattibello lagoon (in blue) and other waterbodies in the area (light blue). Background map from ESRI, HERE, Garmin. 


\subsection{Fish Sampling and Data Analysis}

The fish community was sampled monthly at a fixed station located at the entrance into the lagoon, on one of the two channels that connect it to the Adriatic Sea. The station was positioned at the mouth of the channel for technical reasons, in order to maximize the performance of the fishing gear, i.e., a large, fixed, drop net, much more efficient in a constricted section than in the open lagoon. In the chosen location, this allowed us to efficiently monitor all the migrating species and the lagoonal residents, which visit this area daily at higher hydrodynamism to feed on more diversified macrobenthic community [26].

The results have been analyzed to study the fluctuations of taxonomic and functional diversity, in relation to and for the management of local fisheries, clam aquaculture, and general environmental management for biodiversity conservation.

The analysis was based on 32 sampling events of the fish community carried out during period 2009-2014 (Table 1). Due to meteorological restrictions, samplings were not distributed evenly in the years. Notwithstanding this, all the seasons were sufficiently covered and thus the dataset can properly capture seasonal variations.

Table 1. Number of sampling events by season and year.

\begin{tabular}{cccccccc}
\hline Season & $\mathbf{2 0 0 9}$ & $\mathbf{2 0 1 0}$ & $\mathbf{2 0 1 1}$ & $\mathbf{2 0 1 2}$ & $\mathbf{2 0 1 3}$ & $\mathbf{2 0 1 4}$ & Total per Season \\
\hline Winter & - & 1 & 2 & - & - & 3 & 6 \\
Spring & 4 & 2 & 3 & 3 & 1 & 2 & 15 \\
Summer & - & - & 4 & - & 1 & - & 5 \\
Autumn & - & 1 & 3 & 2 & - & - & 6 \\
\hline Total per year & 4 & 4 & 12 & 5 & 2 & 5 & 32 \\
\hline
\end{tabular}

Fish sampling was performed using a $15 \times 15 \mathrm{~m}$ stationary lift net with an outer and inner meshes of $12 \mathrm{~mm}$ and $8 \mathrm{~mm}$ sizes, respectively. Detailed information on the exact timing of each sampling event is given by Milardi et al. [17]. The lift net was located at the outlet of the Logonovo channel into the Fattibello lagoon, approximately $700 \mathrm{~m}$ from the sea. The Logonovo channel is an extremely simplified habitat, used by fishes for moving to and from the lagoon rather than as a residential habitat. Lift nets are a traditional fishing method in the area and are suitable to capture a comprehensive range of fish sizes; for this reason, they can be used to capture fish movements through the channel (i.e., between the lagoon and marine habitats) and, to a lesser extent, to describe fish community. It also worth mentioning that the sampling gear was not directional, and can only capture the intensity of biotic movements rather than their direction between habitats. All specimens were identified at the species level and were weighted. Non-fish species (e.g., crustaceans) were excluded from the analysis. Since the number of net lifts for sampling event (ranging from a minimum of 12 to a maximum of 32) varied along the considered time span, the results were normalized in catch per unit of effort (CPUE; based on number of net lifts) and were considered both in terms of individual abundance and biomass. The data were aggregated according to seasons with the aim of describing cyclic variation patterns of the functional use of the lagoon throughout the year and, although with some limitation due to the location of the sampling site, the community structure.

The fish community structure was analyzed by means of four taxonomic diversity indexes: Species richness $(S)$, the Shannon-Wiener diversity index $\left(H^{\prime}\right)$, the Pielou evenness index $(J)$, the Simpson index $(D)$. Taxonomic indexes were applied to describe the structures of fish communities in different recent studies [27-29].

Based on Franco et al. [13], the functional use of the lagoon was described by classifying fish species in five use categories (guilds): "Anadromous" (A), migrating from the sea to the lagoon to spawn; "Catadromous" (C), migrating from the lagoon to the sea to spawn; "Freshwater fish" (FW), living in freshwater habitats, accidentally reaching the lagoon from the inland channels; "Marine feeding grounds" (MO), entering in the lagoon for feeding purposes and whose movement can be favored by the tide; "Marine migration" (MM), living in the lagoon as juveniles or larvae stage or adults entering in the lagoon occasionally; 
and "Lagoon resident" (RL), brackish species living in the lagoon for their whole life cycle. The occurrence of species in each functional category in absolute and relative (\%) terms was assessed to describe the functional use of lagoon habitat by fish assemblages.

Community structure indices and functional classifications were applied for both individual abundance and biomass. Seasonal differences were investigated for statistical significances ( $p$-value $<0.05$ ) using multiple range tests based on Fisher's least significant difference (LSD) procedure.

\section{Results}

A total of 34 fish species were identified (Table 2) of which five included in the Habitat Directive: three lagoon residents (grass goby, Adriatic dwarf goby and Mediterranean banded killifish), one anadromous (twaite shad) and one catadromous species (European eel). The latter and almost all the other species are of commercial interest for the fishery sector. Marine feeding ground, lagoon resident and marine migrating species were the most represented groups for functional use $(11,10$, and 9 species, respectively) and accounted for the majority of the observed species. The sand smelt, a lagoon resident, was the only species found in all sampling events, while European anchovy, a marine feeding ground species, was the one with highest mean values of individual abundance and biomass. Two freshwater alien species (common bream and stone moroko) were found only accidentally, in occasions of intense discharge from the two freshwater canals, outflowing in the lagoon western portion, and of a general drop of salinity in the whole basin.

Table 2. List of fish species captured and their respective functional features based on Franco et al. [13] (C = catadromous, $\mathrm{A}=$ anadromous, $\mathrm{FW}=$ freshwater, $\mathrm{MO}=$ marine feeding ground, $\mathrm{MM}=$ marine migratory and $\mathrm{RL}=$ lagoon resident), occurrence (as \% of presence in sampling events), mean individual abundance (ind./CPUE) and biomass abundance (g/CPUE).

\begin{tabular}{|c|c|c|c|c|c|c|}
\hline Scientific Name & Common Name & Family & $\begin{array}{l}\text { Functional Use } \\
\text { of the Lagoon }\end{array}$ & $\begin{array}{c}\text { Occurrence } \\
\text { (\% Sampling } \\
\text { Events) }\end{array}$ & $\begin{array}{c}\text { Mean } \\
\text { ind/CPUE }\end{array}$ & $\begin{array}{l}\text { Mean } \\
\text { g/CPUE }\end{array}$ \\
\hline Anguilla anguilla & European eel & Anguillidae & $\mathrm{C}$ & $37.50 \%$ & 2.44 & 119.58 \\
\hline Belone belone & Garfish & Belonidae & $\mathrm{MO}$ & $6.25 \%$ & 0.09 & 4.17 \\
\hline Abramis brama & Common bream & Cyprinidae & FW & $12.50 \%$ & 0.50 & 2.52 \\
\hline Engraulis encrasicolous & European anchovy & Gobiidae & $\mathrm{MO}$ & $96.88 \%$ & 559.28 & 1570.62 \\
\hline Salaria pavo & Peacock blenny & Scombridae & RL & $6.25 \%$ & 0.06 & 0.15 \\
\hline Chelidonichthys lucerna & Tub gurnard & Triglidae & $\mathrm{MO}$ & $18.75 \%$ & 0.44 & 4.28 \\
\hline Alosa fallax & Twaite shad & Clupeidae & A & $21.88 \%$ & 0.81 & 14.64 \\
\hline Zosterisessor ophiocephalus & Grass goby & Gobiidae & RL & $31.25 \%$ & 0.47 & 6.40 \\
\hline Pomatoschistus canestrinii & Canestrini's goby & Gobiidae & RL & $81.25 \%$ & 5.97 & 6.76 \\
\hline Knipowitschia panizzae & Adriatic dwarf goby & Mugilidae & RL & $50.00 \%$ & 1.56 & 0.45 \\
\hline Pomatoschistus minutus & Sand goby & Blennidae & RL & $9.38 \%$ & 1.72 & No data \\
\hline Gobius niger & Black goby & Gobiidae & RL & $21.88 \%$ & 0.84 & 1.53 \\
\hline Gobius paganellus & Rock goby & Gobiidae & RL & $59.38 \%$ & 4.16 & 35.34 \\
\hline Atherina boyeri & Big scale sand smelt & Atherinidae & RL & $100.00 \%$ & 157.81 & 217.31 \\
\hline Liza ramada & Thinlip mullet & Mugilidae & MM & $84.38 \%$ & 45.72 & 1485.67 \\
\hline Mugil cephalus & Flathead grey mullet & Mullidae & MM & $21.88 \%$ & 0.75 & 25.11 \\
\hline Liza aurata & Golden grey mullet & Mugilidae & MM & $78.13 \%$ & 10.00 & 329.24 \\
\hline Chelon labrosus & Thicklip grey mullet & Moronidae & MM & $9.38 \%$ & 0.56 & 15.23 \\
\hline Liza saliens & Leaping mullet & Mugilidae & MM & $81.25 \%$ & 11.50 & 189.77 \\
\hline Aphanius fasciatus & $\begin{array}{c}\text { Mediterranean banded } \\
\text { killifish }\end{array}$ & Cyprinodontidae & RL & $12.50 \%$ & 0.28 & 0.04 \\
\hline Pagellus bogaraevo & Blackspot seabream & Pleuronectidae & $\mathrm{MO}$ & $3.13 \%$ & 0.03 & 0.13 \\
\hline Ombrina cirrosa & Shi drum & Sciaenidae & $\mathrm{MO}$ & $6.25 \%$ & 0.06 & 2.00 \\
\hline Sparus aurata & Gilt-head bream & Clupeidae & $\mathrm{MM}$ & $25.00 \%$ & 2.63 & 25.90 \\
\hline Plathychtys flesus & European flounder & Gobiidae & MM & $68.75 \%$ & 30.81 & 227.70 \\
\hline Sygnatus acus & Greater pipefish & Sciaenidae & $\mathrm{MO}$ & $65.63 \%$ & 2.38 & 3.64 \\
\hline Sygnathus abaster & Black striped pipefish & Syngnathinae & RL & $25.00 \%$ & 0.47 & 0.42 \\
\hline Pseudorasbora parva & Stone moroko & Cyprinidae & FW & $9.38 \%$ & 10.63 & No data \\
\hline Scophthalmus maximus & Turbot & Soleidae & $\mathrm{MO}$ & $3.13 \%$ & 0.06 & 0.34 \\
\hline Diplodus vulgaris & $\begin{array}{l}\text { Common two-banded } \\
\text { seabream }\end{array}$ & Engraulidae & $\mathrm{MO}$ & $3.13 \%$ & 0.03 & 0.20 \\
\hline Scomber scombrus & Atlantic mackerel & Scophthalmidae & $\mathrm{MO}$ & $6.25 \%$ & 0.34 & 3.39 \\
\hline Solea solea & Common sole & Sparidae & MM & $56.25 \%$ & 8.34 & 18.60 \\
\hline Dicentrarchus labrax & European seabass & Sparidae & MM & $18.75 \%$ & 0.53 & 7.68 \\
\hline Sprattus sprattus & European sprat & Syngnathinae & $\mathrm{MO}$ & $53.13 \%$ & 385.73 & 494.36 \\
\hline Mullus barbatus & Red mullet & Mugilidae & $\mathrm{MO}$ & $25.00 \%$ & 2.72 & 18.78 \\
\hline
\end{tabular}


The seasonal analysis revealed cyclic patterns over time as depicted by the results presented in Table 3. No significant seasonal differences were detected in terms of total individual abundances or total biomass. The results for taxonomic diversity indexes which describe the community structure are also presented in Table 3. Although higher mean species richness $(S)$ was found in spring, the higher biodiversity levels for $H^{\prime}, J$ and $D$ were observed in autumn when considering individual abundances. According to biomass distribution among species, the highest values for taxonomic indexes were instead observed in summer. Winter sampling events showed lower biodiversity levels for both individual abundance and biomass for all the taxonomic indexes.

Table 3. Mean values ( \pm standard error) of individuals and biomass per CPUE, and taxonomic diversity indexes per each season for individual (ind/CPUE) and biomass (g/CPUE) abundances ( $S=$ species richness, $J^{\prime}=$ Pielou evenness index, $H^{\prime}=$ Shannon-Wiener index, $D=$ Simpson index). Letters $(a, b)$ denote statistical significant differences among seasonal values $(p$-value $<0.05)$.

\begin{tabular}{|c|c|c|c|c|c|}
\hline in/CPUE & $S$ & ind/CPUE & $J^{\prime}$ & $H^{\prime}$ & $D$ \\
\hline Winter & $9.67^{\mathrm{ab}}( \pm 0.61)$ & $1358.00^{\mathrm{a}}( \pm 558.5)$ & $0.32^{\mathrm{a}}( \pm 0.11)$ & $0.76^{\mathrm{a}}( \pm 0.26)$ & $0.34^{\mathrm{a}}( \pm 0.13)$ \\
\hline Spring & $13.27^{\mathrm{a}}( \pm 0.75)$ & $1641.53^{\mathrm{a}}( \pm 404.8)$ & $0.46^{\mathrm{ab}}( \pm 0.05)$ & $1.17^{\mathrm{ab}}( \pm 0.12)$ & $0.54^{\mathrm{ab}}( \pm 0.06)$ \\
\hline Summer & $13.00^{\mathrm{ab}}( \pm 1.87)$ & $661.80^{\mathrm{a}}( \pm 202.8)$ & $0.43^{\mathrm{ab}}( \pm 0.09)$ & $1.11^{\mathrm{ab}}( \pm 0.27)$ & $0.49^{\mathrm{ab}}( \pm 0.13)$ \\
\hline Autumn & $10.83^{b}( \pm 1.19)$ & $651.83^{a}( \pm 210.3)$ & $0.61^{b}( \pm 0.06)$ & $1.43^{b}( \pm 0.17)$ & $0.67^{\mathrm{b}}( \pm 0.05)$ \\
\hline g/CPUE & & g/CPUE & $J^{\prime}$ & $H^{\prime}$ & $D$ \\
\hline Winter & & $6252.50^{\mathrm{a}}( \pm 2668.2)$ & $0.36^{\mathrm{a}}( \pm 0.09)$ & $0.79^{\mathrm{a}}( \pm 0.2)$ & $0.36^{\mathrm{a}}( \pm 0.1)$ \\
\hline Spring & & $6063.5^{\mathrm{a}}( \pm 1476.2)$ & $0.57^{\mathrm{b}}( \pm 0.05)$ & $1.18^{\mathrm{ab}}( \pm 0.14)$ & $0.56^{\mathrm{ab}}( \pm 0.06)$ \\
\hline Summer & & $2223.00^{\mathrm{a}}( \pm 789.8)$ & $0.62^{b}( \pm 0.06)$ & $1.58^{b}( \pm 0.21)$ & $0.69^{\mathrm{b}}( \pm 0.06)$ \\
\hline Autumn & & $4003.33^{a}( \pm 1701.2)$ & $0.61^{\mathrm{b}}( \pm 0.07)$ & $1.33^{\mathrm{ab}}( \pm 0.24)$ & $0.61^{\mathrm{ab}}( \pm 0.1)$ \\
\hline
\end{tabular}

Substantial differences between the results of mean individual abundances and mean biomasses among seasons also arise when analyzing the functional use of the lagoon (Table 4). In terms of relative individual abundances (\%), marine feeding ground species prevailed in spring and summers seasons $(76 \%$ and $75.2 \%$ of the total number of individuals per CPUE, respectively), while a more even distribution was observed in autumn with the contribution of lagoon resident species increased up to $35.2 \%$. No significant seasonal differences were observed in terms of absolute individual abundances, except for catadromous and anadromous species. Biomass variations followed different trends. Marine migrating species prevailed in spring, summer and autumn, respectively accounting for the $57.2 \%, 68.8 \%$ and $60.8 \%$ of total seasonal biomasses. However, no significant variation in absolute biomass abundance were observed for marine migrating species, while marine feeding grounds and lagoon resident species significantly decreased in autumn.

Table 4. Mean absolute ( \pm standard error) and relative values of functional use groups per season for individual (in/CPUE) and biomass (g/CPUE) abundances. Letters $(\mathrm{a}, \mathrm{b})$ denote statistical significant differences among seasonal values $(p$-value $<0.05)$.

\begin{tabular}{|c|c|c|c|c|c|c|c|c|}
\hline \multirow{2}{*}{$\begin{array}{l}\text { Functional } \\
\text { Group }\end{array}$} & \multicolumn{2}{|l|}{ Winter } & \multicolumn{2}{|l|}{ Spring } & \multicolumn{2}{|c|}{ Summer } & \multicolumn{2}{|c|}{ Autumn } \\
\hline & ind/CPUE & $\%$ & ind/CPUE & $\%$ & ind/CPUE & $\%$ & ind/CPUE & $\%$ \\
\hline $\mathrm{C}$ & $0.5^{\mathrm{a}}( \pm 0.34)$ & $0.0 \%$ & $1.2^{\mathrm{a}}( \pm 0.8)$ & $0.1 \%$ & $2.2^{\mathrm{ab}}( \pm 2.2)$ & $0.3 \%$ & $7.7^{\mathrm{b}}( \pm 4.0)$ & $1.2 \%$ \\
\hline A & $0.0^{\mathrm{a}}$ & $0.0 \%$ & $0.1^{\mathrm{a}}( \pm 0.1)$ & $0.0 \%$ & $1.0^{\mathrm{ab}}( \pm 0.63)$ & $0.2 \%$ & $3.2^{b}( \pm 2.2)$ & $0.5 \%$ \\
\hline FW & $1.17^{\mathrm{a}}( \pm 0.98)$ & $0.1 \%$ & $23.3^{a}( \pm 23.4)$ & $1.4 \%$ & $0.0^{\mathrm{a}}$ & $0.0 \%$ & $0.0^{\mathrm{a}}$ & $0.0 \%$ \\
\hline $\mathrm{MO}$ & $73.8^{\text {a }}( \pm 27.6)$ & $5.4 \%$ & $133.1^{\mathrm{a}}( \pm 32.2)$ & $8.1 \%$ & $98.4^{\mathrm{a}}( \pm 36.3)$ & $14.9 \%$ & $102.7^{\mathrm{a}}( \pm 31.2)$ & $15.8 \%$ \\
\hline MM & $1227.9^{\text {a }}( \pm 568.4)$ & $90.4 \%$ & $1248.3^{\text {a }}( \pm 350.4)$ & $76.0 \%$ & $498.0^{\text {a }}( \pm 210.9)$ & $75.2 \%$ & $309.2^{\text {a }}( \pm 111.6)$ & $47.4 \%$ \\
\hline RL & $54.5^{\mathrm{a}}( \pm 10.8)$ & $4.0 \%$ & $235.6^{\mathrm{a}}( \pm 118.3)$ & $14.4 \%$ & $62.2^{\mathrm{a}}( \pm 23.6)$ & $9.4 \%$ & $229.2^{\mathrm{a}}( \pm 79.2)$ & $35.2 \%$ \\
\hline Total & $1357.95^{\mathrm{a}}( \pm 558.5)$ & $100 \%$ & $1641.56^{\mathrm{a}}( \pm 405)$ & $100 \%$ & $661.80^{\mathrm{a}}( \pm 203)$ & $100 \%$ & $651.83^{a}( \pm 210)$ & $100 \%$ \\
\hline \multirow{2}{*}{$\begin{array}{l}\text { Functional } \\
\text { Group }\end{array}$} & \multicolumn{2}{|l|}{ Winter } & \multicolumn{2}{|l|}{ Spring } & \multicolumn{2}{|c|}{ Summer } & \multicolumn{2}{|c|}{ Autumn } \\
\hline & g/CPUE & $\%$ & g/CPUE & $\%$ & g/CPUE & $\%$ & g/CPUE & $\%$ \\
\hline $\mathrm{C}$ & $9.7^{\mathrm{a}}( \pm 6.6)$ & $0.2 \%$ & $22.9^{\mathrm{ab}}( \pm 11.1)$ & $0.4 \%$ & $11.3^{\mathrm{ab}}( \pm 11.3)$ & $0.5 \%$ & $553.0^{\mathrm{b}}( \pm 471.3)$ & $13.8 \%$ \\
\hline A & $0.0^{\mathrm{a}}$ & $0.0 \%$ & $6.8^{a}( \pm 5.2)$ & $0.1 \%$ & $19.3^{\mathrm{a}}( \pm 17.4)$ & $0.9 \%$ & $43.5^{\mathrm{a}}( \pm 27.7)$ & $1.1 \%$ \\
\hline FW & $12.6^{\mathrm{a}}( \pm 8.6)$ & $0.2 \%$ & $0.0^{\mathrm{b}}$ & $0.0 \%$ & $0.0^{\mathrm{b}}$ & $0.0 \%$ & $0.0^{\mathrm{b}}$ & $0.0 \%$ \\
\hline $\mathrm{MO}$ & $5050.3^{a}( \pm 2565)$ & $80.8 \%$ & $2302.5^{\mathrm{ab}}( \pm 593)$ & $38.0 \%$ & $496.3^{\mathrm{ab}}( \pm 136)$ & $22.3 \%$ & $441.3^{\mathrm{b}}( \pm 1608)$ & $11.0 \%$ \\
\hline MM & $1036.4^{\text {a }}( \pm 327.9)$ & $16.6 \%$ & $3468.3^{a}( \pm 1081)$ & $57.2 \%$ & $1525.5^{\text {a }}( \pm 269)$ & $68.6 \%$ & $2435.2^{\text {a }}( \pm 1206)$ & $60.8 \%$ \\
\hline RL & $143.5^{\mathrm{a}}( \pm 37.7)$ & $2.3 \%$ & $263^{\mathrm{ab}}( \pm 67.2)$ & $4.3 \%$ & $170.6^{\mathrm{ab}}( \pm 61.2)$ & $7.7 \%$ & $530.3^{b}( \pm 219.5)$ & $13.2 \%$ \\
\hline Total & $6252.42^{a}( \pm 2668)$ & $100 \%$ & $6063.5^{\mathrm{a}}( \pm 1476)$ & $100 \%$ & $2223.04^{\mathrm{a}}( \pm 789)$ & $100 \%$ & $4003.27^{\mathrm{a}}( \pm 1701)$ & $100 \%$ \\
\hline
\end{tabular}




\section{Discussion}

Brackish lagoons are habitat of exceptional value for conservation and their management requires an understanding of how seasonality shapes their biotic community. This is particularly important in the case of Fattibello lagoon, where the demands for fishery and biological conservation need to be harmonized in the context of the wide use of wetlands $[7,30]$. Previous studies have demonstrated the role of meteorological factors [23], moon phases, tide direction and amplitudes [17] in determining fish community composition in the Fattibello lagoon. Such analyses have previously suggested the presence of seasonal effects which should be properly considered in environmental management.

The results of this study have specifically indicated how fish community structure is arranged in response to cyclic variations driven by seasonality, resulting in changes of taxonomic diversity. Interestingly, at the same time, analysis of the fish community highlighted that the lagoon delivers different ecological functions throughout the year. Seasonal patterns of functional use of the lagoon depends on the differences in species ecology. In winter the lagoon mainly exerts the function of feeding ground for marine species, an extremely important function for marine fisheries. During the other seasons, the analysis of biomass abundances reveals both the nursery and feeding functions of the lagoon, in line with other studies carried out in coastal lagoons [31]. In fact, the juveniles of several marine species come into the lagoon in spring and summer to find shelter and trophic resources. Other species, such as anchovy and sprat, perform tidal daily migrations from coastal waters to the lagoon, in order to exploit the high productivity of this hypertrophic environment.

In spring, marine ground species decreased in biomass but not in individual abundance, because of the presence of juveniles. Paradoxically, reproductive patterns are less evident for marine migrating species e.g., Thinlip mullet, in the spring-summer period, as they have different growing dynamics. The use of biomass as indicator for functional use of the lagoon may be more appropriate since it is less sensitive to effects due to the presence of a single species with low body size. For example, a higher individual abundance of European anchovy was found in spring and summer, but this did not correspond to an equivalent prevalence in biomass.

Concerning the trends of total seasonal values, the rather high abundance values in winter months can be explained by two sampling events with extremely high values of total abundances carried out at 12 and 20 March. Although these dates barely fall within the winter period, environmental and meteorological conditions where those typical of the spring season. Significant increases of catadromous and anadromous species in autumn are due to the respective ecology of European eel and Twaite shad).

The relative prevalence of $\mathrm{MO}$ species in winter is mainly due to the high abundances of European anchovy observed in two sampling events on 12 and 20 March 2012, that visited the lagoon for feeding. Even though no direct evidence exists, the rising temperatures may lead this species to start the breeding period earlier inside the lagoon. In fact, lagoons are shallow environments where the ongoing climate change can increase water temperatures in late winter. Such conditions could not only attract the European anchovy in the lagoon for feeding, but also allow us to anticipate their reproduction period. Other studies have demonstrated the influence of temperature variations in the reproductive dynamics of this species [32,33]. If this hypothesis is confirmed, it would provide evidence of how climate change would lead to variations in the functional use of the lagoon.

Therefore, the analysis highlighted is that the lagoon gives

- Reproduction habitats for different species, such as European flounder, European seabass, and different mullet species (mainly thinlip mullet), as well as a habitat for the pre-reproductive period for European anchovy;

- Nursery grounds for a number of commercial species, particularly European eel, mullets, European anchovy, and common sole; 
- Habitats for lagoon resident species, such as sand smelt, black-striped pipefish, Mediterranean banded killifish, and several goby species, supporting them for the whole life cycle.

The findings have important implications for biological conservation and ecosystem services supply and offer relevant evidences of interest for the ecological management of brackish lagoons. In particular, the importance of the lagoon for marine species, which visit the ecosystem for feeding ground or as a nursery habitat, highlights the need to guarantee hydrological connectivity between lagoon habitats and the sea, as demonstrated by other studies [31,34]. In fact, connectivity among marine populations plays a fundamental role in metapopulations dynamics [35] and when connectivity is lost living communities can switch to more simplified structures [34]. The knowledge of how ecosystem functioning of coastal lagoons depends on connectivity to the sea is essential for adequate coastal zone management [36].

Interestingly, the description of structural and functional features by means of individual abundances or by their biomass lead to different conclusions. The analysis of community structure suggests that individual abundance levels are good descriptors of biodiversity levels to support aquatic biological conservation. High values of taxonomic indexes were observed in the autumn season, when the occurrence of marine species, such as the European anchovy and European sprat, which typically visit the lagoon for feeding in summer and first autumn, overlaps with the resident species. This represents a topical information for the biological conservation of the lagoon. In fact, proper environmental heterogeneity should be guaranteed during the autumn period to support a differentiated community and maximize the effectiveness of conservation efforts throughout the year. Additionally, increased abundances of European eel and twaite shad, two endangered protected species, were also observed in autumn. European eel is an iconic species for the area, and its conservation is also source of cultural ecosystem services that should be taken into consideration, such as sense of place of the local community and the conservation of extensive, traditional aquacultural practices.

When considering biomass distribution among species, higher biodiversity levels were found in summer. High values of $H^{\prime}, J$ and $D$ indexes in this period can be explained by an even distribution of biomass, when many species are at their juvenile stages. However, from a protected species conservation perspective, three lagoon resident species are listed in the Habitat Directive. Their protection requires the conservation of the lagoon throughut their whole life cycle. Concerning the analysis of functional groups, biomass was more sensitive to seasonal variations than individual abundance. This aspect should be considered when describing the functional use of lagoons in the context of biological conservation and the wise use of wetland resources.

However, some limitations due to the sampling design of this study should be carefully considered. The sampling site allows us to characterize fish movements but may not completely describe the fish community of the whole lagoon.

Nonetheless, for all the above-reported reasons, and in light of the achieved results, it is evident that the innovative management of this lagoon has to gradually foresee a banning of fishing activities within the area. This is an evident break with historical tradition, but seen in the light of the recent evolution of local fisheries, also becomes strategic for more sustainable and remunerative exploiting of renewable resources. In recent decades, deltas all around the world have experienced a severe simplification and loss of reproductive and nursery habitats, bringing reproduction to critical levels for many species. This dramatic change has rarely been taken into account in the revision of fishery regulations. Thus, it is now far important to restart this dialogue with fishermen and other stakeholders to involve them directly, on the basis of experimental results, in the revision of fishing regulations, promoting full protection of the most sensitive areas. 
Author Contributions: Conceptualization and planning of the design of the study, G.C.; E.A.F. and M.G.; methodology, M.G.; A.G. and M.L.; investigation, M.L. and A.G.; resources, G.C.; data curation, M.G. and M.L.; writing-original draft preparation, M.G.; M.L. and G.C.; writing-review and editing, M.G., A.G. and G.C.; visualization, M.G.; supervision, G.C. and E.A.F.; funding acquisition, G.C. All authors have read and agreed to the published version of the manuscript.

Funding: This work was partially supported by the EU project number PGI04939 “Delta LadyFloating cultures in River Deltas", financed by the European Interreg programme, and "CHANGE WE CARE Climate cHallenges on coAstal and traNsitional chanGing arEas: WEaving a Cross-Adriatic REsponse" (ID:10043385), financed by the European Interreg Italy-Croatia programme.

Institutional Review Board Statement: Not applicable.

Informed Consent Statement: Not applicable.

Data Availability Statement: The data presented in this study are available on request from the first author. The data are not publicly available due to its use for other publications.

Conflicts of Interest: The authors declare no conflict of interest.

\section{References}

1. Pérez-Ruzafa, A.; Marcos, C.; Pérez-Ruzafa, I.M.; Pérez-Marcos, M. Coastal lagoons: “transitional ecosystems" between transitional and coastal waters. J. Coast. Conserv. 2011, 15, 369-392. [CrossRef]

2. Bamber, R.N.; Batten, S.D.; Sheader, M.; Bridgwater, N.D. On the ecology of brackish water lagoons in Great Britain. Aquat. Conserv. Mar. Freshw. Ecosyst. 1992, 2, 65-94. [CrossRef]

3. De Wit, R. Biodiversity of Coastal Lagoon Ecosystems and Their Vulnerability to Global Change. In Ecosystems Biodiversity; InTech: Rijeka, Croatia, 2011; ISBN 978-953-307-417-7.

4. Basset, A.; Elliott, M.; West, R.J.; Wilson, J.G. Estuarine and lagoon biodiversity and their natural goods and services. Estuar. Coast. Shelf Sci. 2013, 132, 1-4. [CrossRef]

5. Resources, W. Resolution VIII.6: A Ramsar Framework for Wetland Inventory. Available online: https://www.ramsar.org/sites/ default/files/documents/library/key_res_viii_06_e.pdf (accessed on 31 December 2020).

6. McInnes, R.J.; Simpson, M.; Lopez, B.; Hawkins, R.; Shore, R. Wetland Ecosystem Services and the Ramsar Convention: An Assessment of Needs. Wetlands 2017, 37, 123-134. [CrossRef]

7. Gaglio, M.; Lanzoni, M.; Nobili, G.; Viviani, D.; Castaldelli, G.; Fano, E.A. Ecosystem Services approach for sustainable governance in a brackish water lagoon used for aquaculture. J. Environ. Plan. Manag. 2019, 62, 1501-1524. [CrossRef]

8. Barbier, E.B.; Hacker, S.D.; Kennedy, C.; Koch, E.W.; Stier, A.C.; Silliman, B.R. The value of estuarine and coastal ecosystem services. Ecol. Monogr. 2011, 81, 169-193. [CrossRef]

9. Gaglio, M.; Aschonitis, V.G.; Gissi, E.; Castaldelli, G.; Fano, E.A. Land use change effects on ecosystem services of river deltas and coastal wetlands: Case study in Volano-Mesola-Goro in Po river delta (Italy). Wetl. Ecol. Manag. 2017, 25, 67-86. [CrossRef]

10. Neori, A.; Agami, M. The Functioning of Rhizosphere Biota in Wetlands-A Review. Wetlands 2017, 37, 615-633. [CrossRef]

11. Viaroli, P.; Bartoli, M.; Vymazal, J. Preface: Wetlands biodiversity and processes-tools for conservation and management. Hydrobiologia 2016, 774, 1-5. [CrossRef]

12. Millennium Ecosystem Assessment Millennium Ecosystem Assessment: Ecosystems and Human Well-Being-A Framework for Assessment. In Assessment; Island Press: Washington, DC, USA, 2003; pp. 44-58.

13. Franco, A.; Franzoi, P.; Malavasi, S.; Riccato, F.; Torricelli, P.; Mainardi, D. Use of shallow water habitats by fish assemblages in a Mediterranean coastal lagoon. Estuar. Coast. Shelf Sci. 2006, 66, 67-83. [CrossRef]

14. Facca, C.; Cavraro, F.; Franzoi, P.; Malavasi, S. Lagoon resident fish species of conservation interest according to the habitat directive (92/43/CEE): A review on their potential use as ecological indicator species. Water 2020, 12, 2059. [CrossRef]

15. Pihl, L.; Cattrijsse, A.; Codling, I.; Mathieson, S.; McLusky, D.S.; Roberts, C. Habitat use by Fishes in Estuaries and Other Brackish Areas. In Fishes in Estuaries; Blackwell Science: Oxford, UK, 2002; pp. 10-53.

16. Fisher, S.J.; Willis, D.W. Seasonal dynamics of aquatic fauna and habitat parameters in a perched upper Missouri River Wetland. Wetlands 2000, 20, 470-478. [CrossRef]

17. Milardi, M.; Lanzoni, M.; Gavioli, A.; Fano, E.A.; Castaldelli, G. Tides and moon drive fish movements in a brackish lagoon. Estuar. Coast. Shelf Sci. 2018, 215, 207-2014. [CrossRef]

18. Watt, S.C.L.; García-Berthou, E.; Vilar, L. The influence of water level and salinity on plant assemblages of a seasonally flooded Mediterranean wetland. Plant. Ecol. 2007, 189, 71. [CrossRef]

19. Amores, M.J.; Verones, F.; Raptis, C.; Juraske, R.; Pfister, S.; Stoessel, F.; Antón, A.; Castells, F.; Hellweg, S. Biodiversity impacts from salinity increase in a coastal wetland. Environ. Sci. Technol. 2013, 47, 6384-6392. [CrossRef] [PubMed]

20. Gavioli, A.; Mancini, M.; Milardi, M.; Aschonitis, V.; Racchetti, E.; Viaroli, P.; Castaldelli, G. Exotic species, rather than low flow, negatively affect native fish in the Oglio River, Northern Italy. River Res. Appl. 2018, 34, 887-897. [CrossRef] 
21. Lynch, A.J.; Cowx, I.G.; Fluet-Chouinard, E.; Glaser, S.M.; Phang, S.C.; Beard, T.D.; Bower, S.D.; Brooks, J.L.; Bunnell, D.B.; Claussen, J.E.; et al. Inland fisheries-Invisible but integral to the UN Sustainable Development Agenda for ending poverty by 2030. Glob. Environ. Chang. 2017, 47, 167-173. [CrossRef]

22. Brummett, R.E.; Beveridge, M.C.M.; Cowx, I.G. Functional aquatic ecosystems, inland fisheries and the Millennium Development Goals. Fish. Fish. 2013, 14, 312-324. [CrossRef]

23. Milardi, M.; Gavioli, A.; Lanzoni, M.; Fano, E.A.; Castaldelli, G. Meteorological factors influence marine and resident fish movements in a brackish lagoon. Aquat. Ecol. 2019, 53, 251-263. [CrossRef]

24. Aschonitis, V.; Castaldelli, G.; Lanzoni, M.; Rossi, R.; Kennedy, C.; Fano, E.A. Long-term records (1781-2013) of European eel (Anguilla anguilla L.) production in the Comacchio Lagoon (Italy): Evaluation of local and global factors as causes of the population collapse. Aquat. Conserv. Mar. Freshw. Ecosyst. 2017, 27, 502-520. [CrossRef]

25. Aschonitis, V.G.; Castaldelli, G.; Lanzoni, M.; Merighi, M.; Gelli, F.; Giari, L.; Rossi, R.; Fano, E.A. A size-age model based on bootstrapping and Bayesian approaches to assess population dynamics of Anguilla anguilla L. in semi-closed lagoons. Ecol. Freshw. Fish. 2017, 26, 217-232. [CrossRef]

26. Fano, E.A.; Mistri, M.; Rossi, R. The ecofunctional quality index (EQI): A new tool for assessing lagoonal ecosystem impairment. Estuar. Coast. Shelf Sci. 2003, 56, 709-716. [CrossRef]

27. Kindong, R.; Wu, J.; Gao, C.; Dai, L.; Tian, S.; Dai, X.; Chen, J. Seasonal changes in fish diversity, density, biomass, and assemblage alongside environmental variables in the Yangtze River Estuary. Environ. Sci. Pollut. Res. 2020, 27, 25461-25474. [CrossRef]

28. Mondal, R.; Bhat, A. Temporal and environmental drivers of fishcommunity structure in tropical streams from two contrasting regions in India. PLoS ONE 2020, 15, e0227354. [CrossRef] [PubMed]

29. Guabiroba, H.C.; Santos, M.E.A.; Pinheiro, H.T.; Simon, T.; Pimentel, C.R.; Vilar, C.C.; Joyeux, J.C. Trends in recreational fisheries and reef fish community structure indicate decline in target species population in an isolated tropical oceanic island. Ocean. Coast. Manag. 2020, 191, 105194. [CrossRef]

30. Hettiarachchi, M.; Morrison, T.H.; McAlpine, C. Forty-three years of ramsar and urban wetlands. Glob. Environ. Chang. 2015, 32, 57-66. [CrossRef]

31. Davis, B.; Johnston, R.; Baker, R.; Sheaves, M. Fish Utilisation of Wetland Nurseries with Complex Hydrological Connectivity. PLoS ONE 2012, 7, e49107. [CrossRef]

32. Hernández-Santoro, C.; Contreras-Reyes, J.E.; Landaeta, M.F. Intra-seasonal variability of sea surface temperature influences phenological decoupling in anchovy (Engraulis ringens). J. Sea Res. 2019, 152, 101765. [CrossRef]

33. Contreras-Reyes, J.E.; Canales, T.M.; Rojas, P.M. Influence of climate variability on anchovy reproductive timing off northern Chile. J. Mar. Syst. 2016, 164, 67-75. [CrossRef]

34. Obolewski, K.; Glińska-Lewczuk, K.; Astel, A. Lost connectivity between a coastal lagoon and the sea-Implications of floodgate closure for benthic macroinvertebrates. Estuar. Coast. Shelf Sci. 2018, 211, 77-89. [CrossRef]

35. Carson, H.S.; Levin, L.A.; Cook, G.S.; López-Duarte, P.C. Evaluating the importance of demographic connectivity in a marine metapopulation. Ecology 2011, 92, 1972-1984. [CrossRef] [PubMed]

36. Pérez-Ruzafa, A.; De Pascalis, F.; Ghezzo, M.; Quispe-Becerra, J.I.; Hernández-García, R.; Muñoz, I.; Vergara, C.; Pérez-Ruzafa, I.M.; Umgiesser, G.; Marcos, C. Connectivity between coastal lagoons and sea: Asymmetrical effects on assemblages' and populations' structure. Estuar. Coast. Shelf Sci. 2019, 216, 171-186. [CrossRef] 